\title{
The Role of Parents in the Prevention of Cyber Bullying in Covid 19 Pandemic
}

\author{
Nursariani Simatupang ${ }^{1, *}$
}

\author{
${ }^{1}$ Faculty of Law Universitas Muhammadiyah Sumatera Utara, Indonesia \\ *Corresponding author. Email: nursarianisimatupang@umsu.ac.id
}

\begin{abstract}
Before the covid 19 pandemic, children studied at school and interacted directly with their friends including the practice of direct bullying. Children can not learn and interact directly, because they have to learn online from home. Learning online using information technology devices such as smartphones. Means that children are also given an option to access social media, as a means of interacting with their friends. This can cause problems because in their use they can be involved in cyber bullying, as a result of not being able to meet in person. During the covid 19 pandemic, the children continue with their smartphone without the full supervision of parents. The lack of parental supervision, gives them chances to easily insults or taunts at someone they do not like through social media. Bullying has a negative effect especially on victim. Seeing these negative impact the role of parents in the prevention of bullying by children in the covid 19 pandemic should be optimized. The purpose of the research is to analyze the impact of cyber bullying by children and analyze the role of parents in the prevention of cyber bullying in the covid 19 pandemic. The research is normative juridical research. Documentation study was used as the technique to collect the data. The research discovered cyber bullying causes negatively affects to a child, and can traumatize a child as a victim. The trauma make the children become lazy, such as the feeling of being ashamed to meet his friends, lazy to learn, and even depressed. On the other hand, bullying has legal consequences for the perpetrator. Children can not be left alone to use their gadgets on the learning online in the time of the covid 19 pandemic. Full parental assistance and supervision of the child are required in the use of gadgets. Despite being busy with their work, parents should always keep an eye on all children's activities. Parents should always accompany and know what the child is doing, especially when the child uses his/her smartphone in online learning activities.
\end{abstract}

Keywords: Role, Parents, Prevention, Cyber Bullying, Child, Covid 19 Pandemic.

\section{INTRODUCTION}

In the pandemic, the children must be studied with online system. Online system make children using technology information. Technology information that often used by children is smartphone.

The lack of parental supervision, chidren can use smartphone for explore at social media. But, by social media, children can do negative activities like bullying.

The purpose of this study is to analyze the impact of cyber bullying on children and analyze the role of parents in the prevention of cyber bullying in the covid 19 pandemic.

\section{RESEARCH METHOD}

The research is normative juridical research, namely research with an approach conducted based on legal materials, by studying literature materials, in the form of legal principles, concepts, and related legislation.

The study uses secondary data, consisting of primary, secondary, and legal materials. The data collection tool used is a documentation study. 


\section{FINDINGS AND DISCUSSION}

\subsection{The Impact of Cyber Bullying}

Bullying is a situation where an abuse of power or power is committed by a person or group. A strong side here not only means strong in physical size, but can be mentally strong. In this case the victim of bullying was unable to defend himself or herself due to being physically

and/or mentally weak. What is necessary and important to note is not just the actions taken, but the impact of such actions on victims [1].

According to Ken Rigby the definition of bullying is a desire to hurt. This desire is shown into action, causing a person to suffer. This action is performed with pleasure directly by a stronger, irresponsible, recurring group. [2]

Bullying is [2]

a. The criminals deliberate actions to his victims, not an omission and completely intentional.

b. That action happens over and over again. Bullying is never done randomly or just once.

c. Based on striking power differences.

The bullying category includes the following 5 categories [2], first, physical (punching, pushing, biting, punching, kicking, locking someone indoors, pinching, clawing, also including blackmailing and damaging items owned by others). Second, verbal (threatening, humiliating, demeaning, harassing, name-calling or name calling, sarcasm, demeaning or put downs, denouncing or mocking, intimidating, slurring, spreading gossip). Third, non verbal (pasting a demeaning, mocking or threatening facial expression usually accompanied by physical or verbal bullying). Fourth, non verbal behaviors are indirect (silence a person, manipulate friendships so that they become fractured, deliberately ostracized or ignored, sending canned letters). Fifth, sexual harassment (sometimes categorized as physical or verbal aggressive behavior).

Adverse effects that can occur in children who are victims of bullying, such as anxiety, feeling lonely, low self-esteem, low levels of social competence, depression, social withdrawal, complaints on physical health, getting out of the house, alcohol and drug use, suicide, and reduced academic performance. While the doer of bullying is not separated from the following risks, often fighting and injury, stealing, drinking alcohol, smoking, being a slob at school, staying out of school, fond of carrying sharp weapons, the worst is being a criminal [3].

As for those who used to witness acts of bullying, are become afraid children, often anxious, and a low sense of self-security.
Cyber bullying is bullying that takes advantage of the development of technology, such as the internet and electronic facilities. From these tools, perpetrators can send threatening text messages, images or videos, spread rumors, and terror. This not only hurts the victim, but can also embarrass them, because what has been uploaded to the internet will usually be so widespread that it is difficult to remove [4].

Cyber bullying negatively affects children, both as victims and children as perpetrators. To victims, cyber bullying can traumatize a child. The trauma resulted in the child's ineffectiveness doing his daily activities, such as the victim's being ashamed to meet his friends, lazy to learn, or even the feeling of depressed. On the other hand, bullying has legal consequences in the form of funding for the perpetrators.

All forms of bullying are either mild or severe, still will make the victim depressed. Especially if the action is repeated in different places. If a person becomes a victim of bullying for longer, he or she will become more and more caught up in a negative dynamic and the perpetrators will take more various actions against him. [4]

According to Duncan there are a number of several characteristics of bully perpetrators, among others, namely [4] performing repetitive aggressive behaviors lacking compassion in relationships, being positive-minded towards violence, experiencing confusion at theirselves, develop patterns of impulsive behavior, replacing or channeling anger at others, switching from victim to perpetrator, feeling insecure and anxious, anti social and isolated, having a grudge , hate, and frustration, have an unrealistic positive self view, are unable to adjust to new expectations, show social discomfort, are often unconscious and do not care about the grudge of their victims, exiled from schoolmates or peers.

\subsection{The Role Of Parents In Preventing Cyber Bullying During the Covid 19 Pandemic}

Smartphone use in children is increasing especially during the covid 19 pandemic. This is due to the implementation of the online learning system. Children use smartphones as a means of learning. However, without strict supervision, the child can switch to opening and surfing on his social media, which is very vulnerable resulting in bullying in other children. Especially now they can't meet in person at school.

Social media is used as a means of disseminating information. Which is expected to be the correct information and useful to the community. Also social media serves to expand the friendship network. However, social media is also particularly vulnerable to being used to spread taunting, insulting, hateful 
sentences. The purpose of cyber bullying is usually to humiliate, alienate, and damage the reputation of others socially. Social media, it can be seen and read by the public overall and indefinitely.

Through social media, children can convey incorrect information about their friends, deliver sentences that provoke fights or commotion, and upload photos or videos that provoke outrage. Even children can perform do a "comment war" accompanied by a disrespectful sentence. Through social media, children can shed their anger, hatred, and displeasure to the other side. They can easily pour what he feels, without thinking about the adverse effects of his actions. Without parental supervision, it is very difficult to control their activities on social media.

Children can not just be left using smartphones on the grounds of learning online in the time of the covid19 pandemic. Full parental assistance and supervision of the child are required in the use of gadgets. Despite being busy with their work, parents should always keep an eye on all children's activities. Parents should always accompany and know what the child is doing, especially when the child uses a smartphone in online learning activities. So that the child always learns well and does not browse on his social media that may result in bullying in other children.

Parents often do not supervise the child's actions especially when learning online. There is a presumption that if over supervised, the child will not be able to become an independent learner. Or worried parents are considered authoritarian figures. Many parents too trust of their children.

Erroneous parental perception [2] in the children's behavior is:

a. Children are considered to be able to adjust themselves to hanging out in their environment, then the parents do not care and believe in the children's environment. This view is not entirely true. Although the child has been trusted by parents, and is naturally in compliance with the environment, parents should keep an eye on and be able to spend their time knowing the child's behavior and environmental situation, including the school environment.

b. Children are opened to their parents, it has been believed by parents that the children's real behavior. This opinion is not entirely true. Although the child, has been seen to be open to parents and trustworthy, not necessarily that behavior is the child actual behavior. Children still easily changes his behavior by the influence of conditions outside his environment. Children also often act manipulatively. Children can lie and can cover up the real situation for a reason (for example to please parents or to get something). Therefore, parents should keep an eye out for information about the child true condition.

c. Teenagers will tend to be closed and behave strangely. Therefore there are parents who feel no need to urge themselves to know everything that the child is going through. This view is not necessarily true. Dealing with a closed or strange children should instead motivate parents to try to get information about the children condition and the situation in which the children is located. People know they have to work hard to be able to communicate with children of this type, because children of this type often have a lot of problems. Therefore, it is necessary for the preparation and seriousness of the parents to know and engage in the world of their children.

The role of parents in a family is indispensable in supervising their child, especially in the use of smartphones. Without parental supervision, several negative impacts that arise, namely;

a. Children learn negative matters.

Sutherland (a pioneer of differential association theory) argues that criminal behavior is a behavior studied in a social environment, meaning all behaviors can be learned in a variety of ways. He also stressed that all behaviors can be learned. So is criminal behavior. Criminal behavior is learned in interactions with others through a communication process.

Before a person commits a criminal act, including a child, he or she has gone through the process of learning about the crime. These crimes can be learned in daily life, whether using technology or not. Nowadays, with information technology, children will learn more about things, both positive and negative. With a smartphone within reach of their finger, it is easy for a child to see, read, or hear existing content. Unfortunately, not all of this content is positive content for a child.

b. Children are more likely to commit crimes.

Because humans have the natural ability to imitate, a child can easily imitate something. The ability to imitate something that exists is one of God's gifts from man that is invaluable.

Impersonation or imitation is one of the aspects of learning activities imitating the behavior of others, so by various psychologists imitation is seen not as a characteristic of human carrying, but rather as a social process that allows the increasing participation of a person in groups/communities [5]

Continuous imitation of an impersonation object will result in a second entity that may differ from the innate character. Man imitates almost everything he can emulate including evil [5] 
The imitation process did not occur immediately. According to the Chorus, the imitation process requires several conditions to be met, namely [5] there is considerable interest or concern for what is imitated, the attitude of upholding or admiring what will be imitated, depending on the understanding, level of development, and level of knowledge of the individual who will imitate.

Impersonation in society does have a huge influence. Although every human life is very distinctive, it can be agreed, that many people, including children, in their habits and opinions strongly follow the state of their environment.

If the child is accustomed to learning the negative things, he or she gets from a smartphone, the child will be easier to perform bad actions, contrary to societal norms. Furthermore, the child will easily become the perpetrator of actions that violate the norms of the law. Children will be easier to be the next offender.

A type of crime often easily committed by a child is bullying another child through social media. Without shame or feeling of guilt, the child easily commits acts that violate norms, including violating legal norms. The child makes a mockery, insult, or inappropriate word towards someone he does not like. In fact, the child is accustomed to getting into fights with disrespectful sentences through his own social media.

There are several important things as a form of intervention on bullying, which is important to note, the early intervention is very important, the doer must be responsible for their actions, the parent must be responsible for their children [2].

In order for the child not to commit criminal acts in the form of cyber bullying, parents should take precautions in the form of stricter supervision to children, especially in use of smartphones, are:

a. Knowing the child's personality.

b. Knowing the child's learning schedule provided by the school.

c. Knowing the materials and tasks given by the teacher to the child.

d. Accompaning the child while taking lessons with the online system.

e. Accompaning the child while doing tasks given by teachers in the online learning system.

f. Knowing the activities carried out by the child using his smartphone.

g. Knowing the password of the child's smartphone.

h. Knowing the child's social media password.

i. Knowing the child's friends either at home, on social media or at school.

Practical efforts in supervising, guiding, and intervening in cases of bullying; are to provide examples of how good friends are, to give examples to students to control themselves, to provide explanations that violent aggression is unacceptable, to stop any symptoms of an act of aggression immediately, to identify and name the effects of aggression, to describe or explain the victim's condition of aggression behavior, and to teach empathic and guiding relationship patterns [2]

Family is the most important part of a child's life. In the family, the child begins to learn about many things, especially from his parents. In family learning, the child must obtain supervision from his or her parents.

In addition to those outlined earlier, here are some efforts that can be made by parents, to prevent cyber bullying by children, namely:

a. As a form of parental supervision in the prevention of cyber bullying measures by the child, it is recommended that parents always motivate the child to behave properly.

There are three important elements of motivation, namely:

1) Motivation initiates a change in the energy in each human being. The development of motivation will bring some energy changes in humans.

2) Motivation is characterized by the appearance of feeling, a person's affection. Motivation is relevant to psychiatric, affection, and emotional issues that can determine human behavior.

3) Motivation will be stimulated because there is a purpose. Motivation is the response to an action that is the goal. Motivation arises from within man, but its appearance is driven by the absence of other elements, in which case it is the purpose. This goal will concern the needs.

In children, motivation should be given as often as possible so that they can discipline themselves. The child should better understand that they are the next generation of the nation. If they become perpetrators of bullying at a young age, it will certainly become easier for them to become perpetrators of other crimes in the future.

Parents should be able to turn on and motivate the child for a conducive interaction process at home.

To foster a child's mental, behavior, and personal attitudes, parents should be wiser and more careful in their approach. It takes proficiency in directing motivation and thinking by not forgetting to use the parent's personality as a model for the child. Therefore, a parent must also always do good actions to help motivate the child with better attitudes. Especially in smartphone use, parents should use it only for good purposes.

The formation of a child's mental and behavioral attitudes, will not be separated from the planting of values in the daily life of the child, especially in a 
family. Parents, it should transfer good values to the child.

As it is expected to grow awareness and willingness of a child to do good things for his future, especially the good things he has gained from his parents.

b. Understanding that cyber bullying is a possible act criminal.

Cyber bullying is considered an action that can occur, especially when one feels hurt or angry with others party. Some even have the understanding that, bullying is a surefire action to reduce heartache or anger to others. Children should be told that cyber bullying is an act that may end up with a punishment.

c. Understanding the impact of cyber bullying.

Children should be informed that cyber bullying has a devastating impact, both on the victim and on the performer.

The fundamental concept that needs to be prepared towards change is that there is knowledge, understanding, or vision of bullying, including targets and changes, there is self efficacy to change bullying, there is motivation to change bullying, there is a willingness to communicate with the school community, there are pros of cons or dissatisfaction (dissatisfaction) on the issue of bullying and its methods of handling are discussed together, there are first steps to be taken, including communicating and organizing members in the network according to their vision, targets and objectives [2]

d. Providing educational punishment.

One way of preventing children from bullying is by not committing child abuse in the family. In the process of interacting with his environment, the child occasionally commits mistakes. If this happens, the punishment should be educational punishment. The punishment given is a one that can change the behavior and morals of the child, and is not accompanied by acts of violence. This will close the possibility of the child to commit imitate violence on the other side, as a result of the acts of violence received from his parents. The process of disciplining a child should be conducted with compassion and should be aimed at helping them find themselves.

Overcome, prevent disciplinary problems and try to create a pleasant atmosphere in the family, so that the young do not grow into criminals of inappropriate actions, incompatible with the norm, even breaking the law, among others doing cyber bullying.

e. Building good communication with the child and teach the child about the ethics of communication.

The role of parents in bullying is to be able to provide the latest information to the child, as the first person who can accompany and protect the child in an atmosphere of love [2].
To prevent unwanted actions and circumstances, a thorough intervention is required where the parental network can engage all members of the community to be aware of and prevent aggressive behavior and its consequences. Therefore, it is necessary to first improve communication with the child. So that the child's relationship with parents becomes more honest and open. Second, staff and school administrators understand the issue of bullying and its consequences, providing information and taking action against bullying. Third raises awareness of staff, students, and parents over the issue of bullying. The fourth confirms where the bullying occurred. The fifth sets a baseline to measure the condition of bullying after intervening. The sixth contacted experts, such as psychologists, legal experts, police, and other observers [2]. In addition, parents should always teach the ethics of communicating to the child to prevent the child from harm.

Some of the methods and training that have been done in schools in the United States, Australia, and Erofa as well as other countries are:

1) Peer partnering/befriending. Part of a pro-social intervention strategy through the use of peer groups to protect, accompany or care for vulnerable young and frail pupils as victims of bullying. These activities are provide and lessons to be confident, and skilled at making school work, being adaptable, and expand friendships.

2) Peer mentoring. Know, talk, empathize, and accompany students, and the lessons they gain. Guide students to gain self-esteem to be confident, able to solve problems and have meaning for others. Mentoring can be done with role play.

3) Effective counseling and mediation. Actively listening, being able to provide feedback on the problems faced by students, using method that focuses on feeling.

4) If there is bullying involving a group, then the group must take responsibility for doing something to improve attitudes especially towards the victim and her community.

5) Collect, select, and process the latest data and information with fellow parents, teachers, and students and others who are aware of the problem of bullying. Such a supporting network, is generally done face to face, and through the use of human computer interaction and technology from cyberspace.

6) Packages involves all parties in the school, namely staff, teachers, parents of students, and students. These activities include disseminating booklets or posters in many places containing messages of solidarity, love of solidarity among others, appreciation, honesty, and trust.

7) Control and communicate with the child. Invite children to be able to communicate and express 
opinions about everyday problems. Controls are in place to determine the child's condition without the intention to curb the child's freedom.

8) Cognitive social intervention, which assigns children and parents and adults to protect the child from violence. Establish a learning environment that focuses on non-aggressive physical and social skills.

\section{CONCLUSION}

Cyber bullying has negative consequences that can cause trauma to children as victims. As the victim, children would be ashamed to meet his friends, lazy to learn, even depressed. Bullying has legal consequences in the form of punishment for perpetrators. Children can't just be left using smartphones on the grounds of learning online in the time of the covid-19 pandemic. Full parental assistance and supervision of the child are required. Despite being busy with their work, parents should always keep an eye on all children's activities. Parents should always accompany and know what the child is doing, especially when the child uses his/her smartphone in online learning activities. So that the child always learns well and does not acces social media.

\section{REFERENCES}

[1] Ariobomo Nusantara, Bullying Mengatasi Kekerasan di Sekolah dan Lingkungan. 2014.

[2] Ponny Retno Astuti, Meredam Bullying: 3 Cara Efektif Menanggulangi Kekerasan pada Anak. Jakarta: Grasindo, 2008.

[3] Andri Priyatna, Let's End Bullying, Memahami, Mencegah, dan Mengatasi Bullying. Jakarta: Elex Media Komputindo, 2010.

[4] Paresma Elvigro, Secangkir Kopi Bully. Jakarta: Elex Media Komputindo, 2014.

[5] Tubagus Ronny Rahman Nitibaskara, Ketika Kejahatan Berdaulat. Jakarta: Peradaban, 2001. 